\title{
歯周病変のある根分岐部のエナメル小滴とセメント粒の 走査電顕および透過電顕による研究
}

\author{
荻野 智子松江一郎 \\ 近野三江子* 菅 原 信 一* \\ 日本大学松戸歯学部保存歯周病学教室 \\ (主任 : 松江一郎教授) \\ *鶴見大学歯学部口腔病理学教室 \\ (主任 : 菅原信一教授) \\ (昭和 56 年 12 月 20 日受付)
}

\section{SEM and TEM Study of Enamel Droplet and Cementicle in Furcation Involvement}

\author{
Tomoko OGINO, Ichiro MATSUE, \\ Mieko KONNO* and Nobukazu SUGAWARA* \\ Department of Periodontology \\ Nihon University School of Dentistry at Matsudo \\ (Director: Prof. Ichiro MATSUE) \\ *Department of Oral Pathology \\ Tsurumi University School of Dentistry \\ (Director : Prof. Nobukazu SUGAWARA)
}

This study was an attempt to investigate electron microscopical difference between enamel and enamel droplet, and cementum and cementicle in periodontal disease.

A total of 41 molar teeth with furcation involvement and impossible of preservative treatment were used in this investigation. Those teeth were fixed in $10 \%$ neutral formalin, the moment they were extracted. Soft tissues from most of the samples were removed with ethylendiamin. Enamel droplet and cementicle in surface of root furcation were observed under the SEM and TEM. The ground section were also prepared and observed by polarized light microscopy and microradiography.

It was observed in the root furcation that such an aberration was a strong predisporing factor in the initial break down where enamel projection was present.

SEM and TEM finding revealed that surface of the enemel droplet and cementicle in the furcation were different from normal enamel and cementum.

本論文の要旨は, 昭和 54 年 11 月第 22 回 秋季日本歯周学会 総会および昭和 55 年 6 月第 58 回国際歯科学会 (IADR) にお いて発表した。 


\section{I. 緒言}

歯周疾患の発症の病因は，様々な因子の複雑な関連よ り成立している。关の発症と進行の各因子に対して多様 なる治療法が試みられているが1)，治療後の結果が思わ しくない症例も多い2。

特に，多根歯における根分岐部は，発生学的にも形態 学的にも複雑であり ${ }^{3,4,5,6)}$, その部位に存在するエナメ ル突起やエナメル小滴 $\left.{ }^{7}, 8\right)$ が, 根分岐部病変の発症に関し て重要な意義をもっていることが古くから論ぜられてい る $^{9,10,11,12)}$ 。根分岐部の形成に関しての大 江 $^{13,14,15,16)}$,

Kovacs $^{17)}$, J $\phi$ rgersen $^{18)}$ 等の研究による, 根の形成, 根 分岐部の形成に対寸る新知見からも，根分岐部の治療法 上, エナメル突起, エナメル小滴の分布状態, 頻度など をさらに明らかにすべきである。

従って, 我々は, 根分岐部病変の病理組織学的検索を

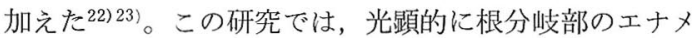
ル小滴，セメント粒の分布とその頻度を明らかにするこ とができた。しかし，その詳細，特に電顕的な微細構造 と立体構造，そしてエナメル小滴，セメント粒との相互 関係等を明らかにすることが必要であると考えられる。 よって，歯周疾患罹患歯におけるエナメル小滴やエナメ ル小滴を覆っているセメント質の構造とエナメル質や正 常セメント質との構造に相違があるかどうかについて観 察を行い，それらの所見について報告をする。

\section{II. 研究材料および方法}

研究に用いた歯は，歯周疾患に罹患し，治療不可能で 要抜去と診断し，拔去した大四歯 41 本について検 索を 加えた。拔歯直後, $10 \%$ 中性ホルマリンにて固定保存さ れた。

それらは, 実体顕微鏡で倠察後, 走査電顕用試料を作
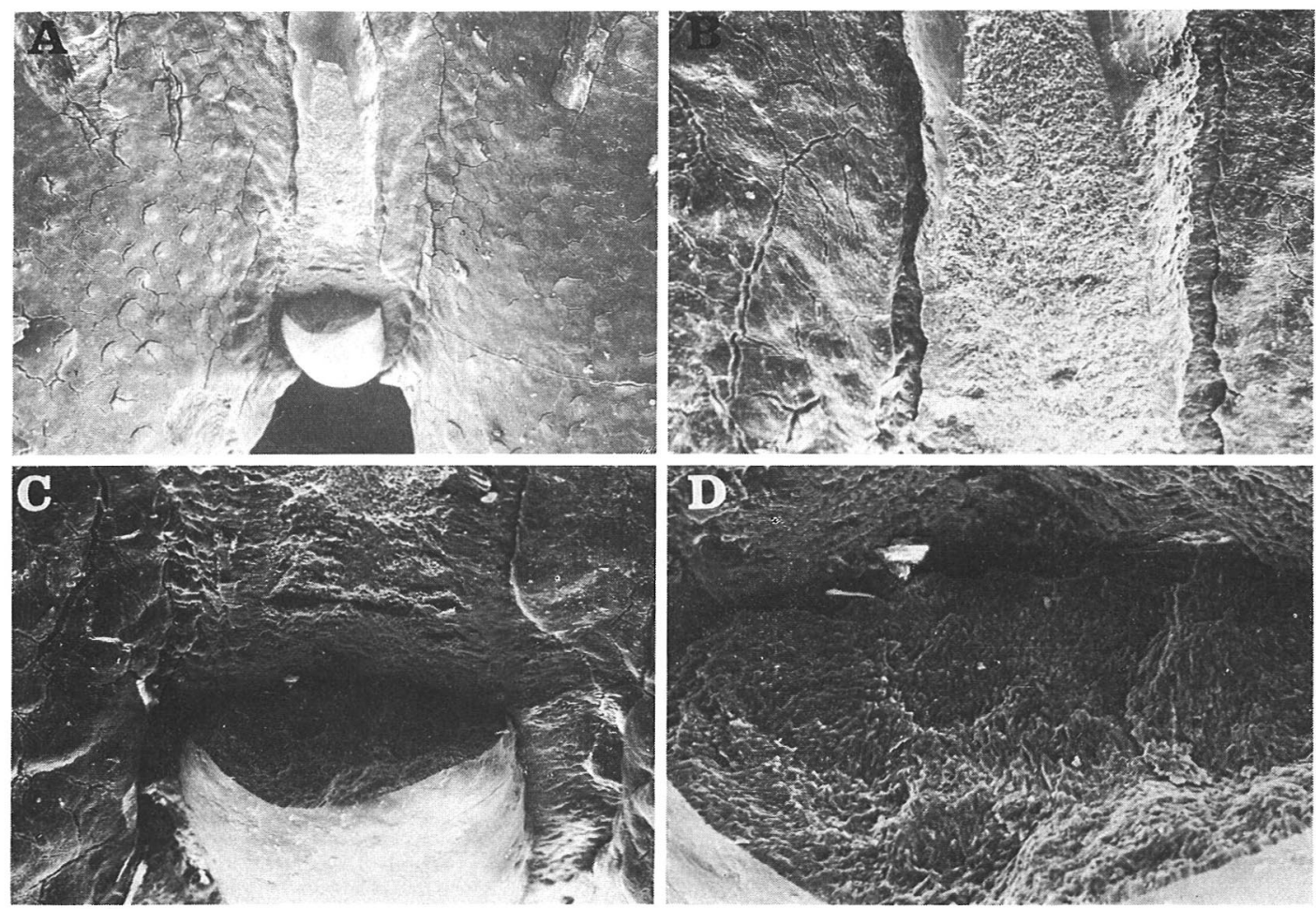

図 1-1 エチレンジアミン原液 $60^{\circ} \mathrm{C}, 48$ 時間処理
A : $\times 30$ シャーピー線維の付着部がウロコ状に観察される。
B : ×100 分岐部へ伸びているエナメル突起
C : $\times 100$ エナメル突起の破断面
D : $\times 300$ 
成するために流水中で 1 日水洗後エチレンジアミン原液 中にて, $37^{\circ} \mathrm{C} 48$ 時間, · $60^{\circ} \mathrm{C} 24$ 時間 · 48 時閒 · 72 時閒 作用させ有機物を除去した。

処理された歯は, 水洗後, 煩側根分岐部が中心となる ように $5 \mathrm{~mm}$ 7 $\mathrm{mm}$ の長方形の小片に切り出された。 小片は通法に従い脱水, 脱アルコール後, 日立社製 HCP-1 型を用いて臨界点乾燥を行い，エイコーエンジ ニアリング社製の Ion Coater IB-5 型で白金蒸着をさせ, 日立社製の HSM-II A 型走查電顕にて, 加速電圧 $20 \mathrm{kv}$ で観察をした。観察後小片はリゴラック樹脂に包埋し， 頓側根分岐部を含むように煩舌方向に厚さ約 $50 \mu$ の研 磨切片を作成し，偏光顕微鏡で観察し，さらにミクロラ ジオグラムを撮影した。な拝, 抜去歯の一部分は, セメ ント粒の微細構造を調ベるため, $5 \%$ EDTA により脱灰 を行い透過電顕用試料を作成した。

\section{III．所見結果}

\section{〈エナメル突起の走査電顕による観察〉}

歯周病変が存在する根分岐部を走査電顕で検索を行う と，エナメル突起が観察される症例が多い19)。それらの エナメル突起の形態や分布は様々な状態を示し，たとえ ば，歯頸部付近にとどまるもの，あるいは歯根分岐部深
くまで伸びているものもある20)。また，そのエナメル突 起の周囲や先端がセメント質に覆われている場合が多数 認められた。エナメル突起の表面は, それに続いている 歯冠部のエナメル質の表面となんら相違は認められな い。そして，表面には，エナメル小皮と思われる一層の 膜状物が被覆しているようにみえる部分も存在した。し かし, エナメル突起の破断面において, 小柱構造は認め られなかった（図 1-1）。

〈エナメル滴の走査電顕による観察〉

試料に用いた歯をエチレンジアミン原液にて線維組織 の除去を行うと, 根分岐部中央にまで, セメント質に囲 まれた浅い凹みとなって根面に露出しているエナメル質 表面が認められる(図 2-1 A) (図 3-1 A，B)。

この表面は, 低倍率では比較的平滑であり（図 3-1 B), エナメル突起の表面とほぼ同様で, 線維の埋入は認めら れない。

くセメント質表面の走査電顕による観察 $>$

症例 1 (図1-2) の歯をエチレンジアミン原液 $60^{\circ} \mathrm{C} に$ て 48 時間作用させると, セメント質表面が露出され, シャーピーの線維束の付着部と思われる部分がウロコ状 に認められる（図1-1A）。

症例 2 (図 2-2) は, エチレンジアミン原液 $60^{\circ} \mathrm{C} 72$ 時 間処理を行った（図 2-1）。すると，分岐部にはセメント

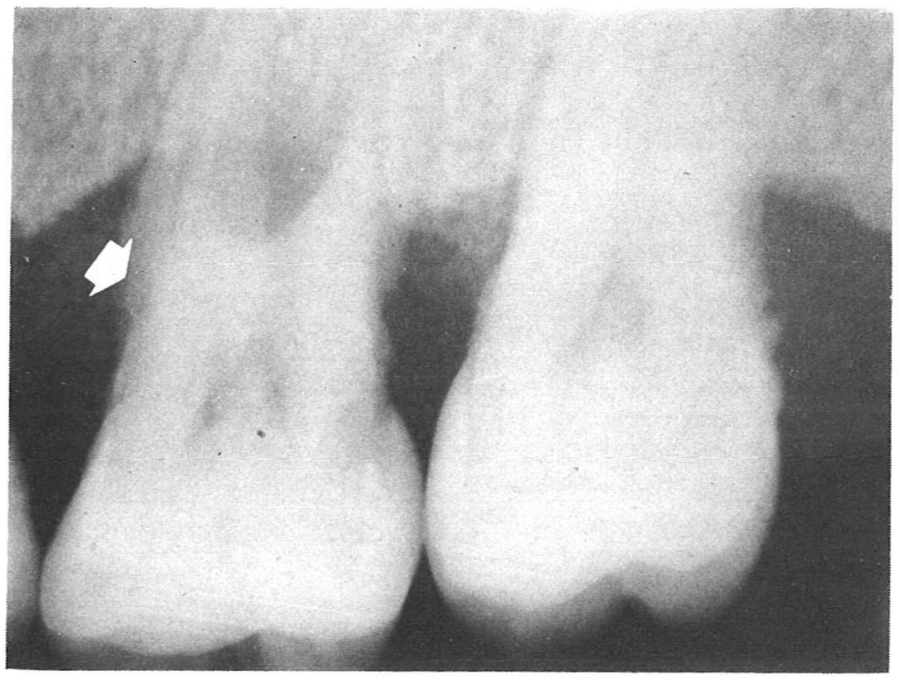

図 1-2 症例 1

우 38 歳 6

8 年前より歯の動摇を自覚し, 歯周ポケット測定值は口盍側 $6 \mathrm{~mm}$, 煩側分岐部 $10 \mathrm{~mm}$ であった。昭和 54 年 3 月 1 日に抜歯。類側より 分岐部中心に達する病変が存在し, X 線写真上に おいて 分岐部歯槽 骨の透過像が認められた。 

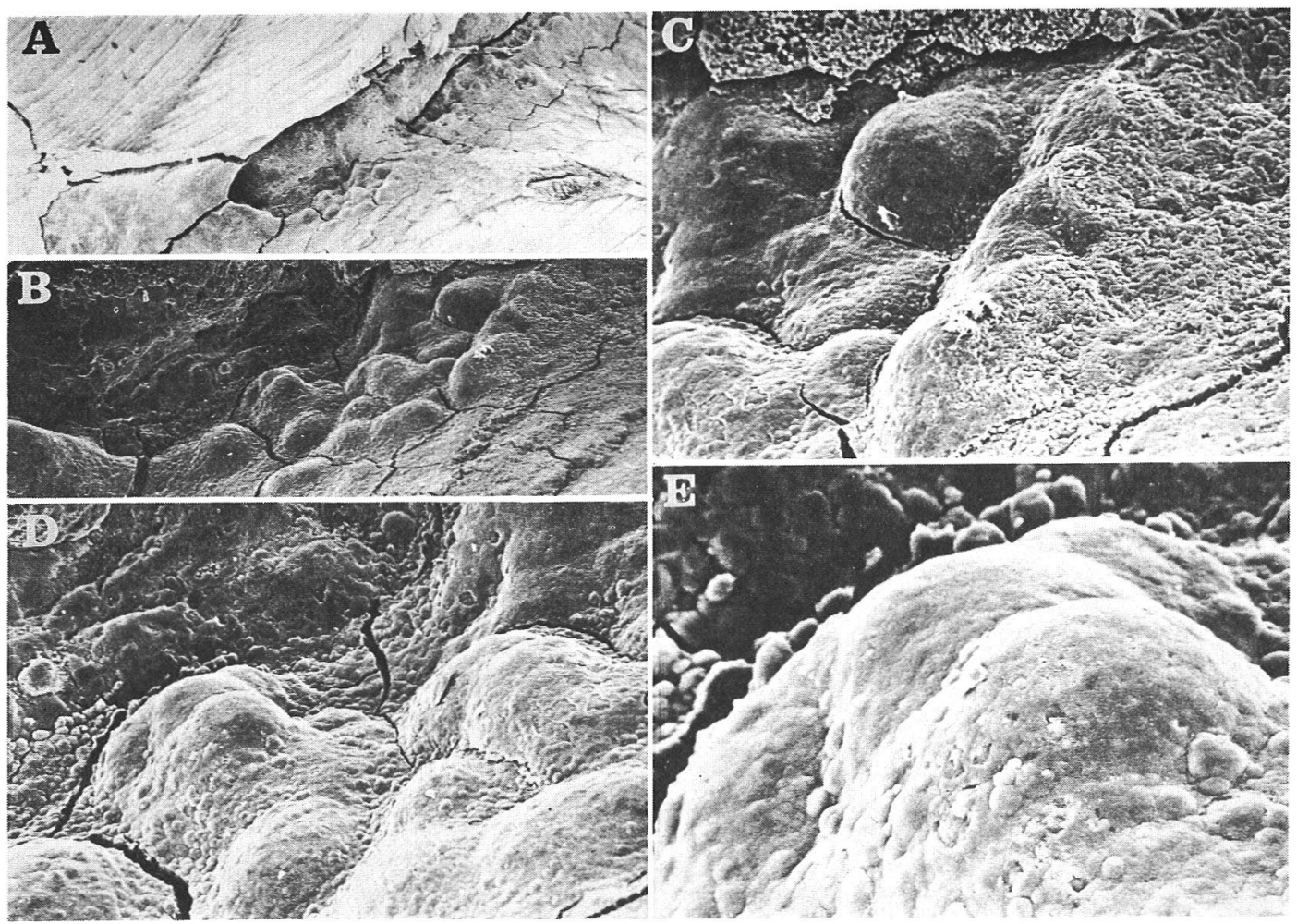

図 2-1 エチレンジアミン原液 $60^{\circ} \mathrm{C}, 72$ 時閒処理
A : $\times 30$
B : $\times 100$ 七メント粒と思われる半球状隆起
C : $\times 300$
$\mathrm{D}: \times 300$
$\mathrm{E} ： \times 100$ 半球状隆起物の表面にはさらに小さな隆起が認められる

質から露出しているエナメル突起の先端部，もしくは， エナメル小滴と思われる部分の周囲セメント質を観察す ると，半球状の隆起が集合しているのが認められる。こ れは，我々の研究報告 ${ }^{22)}$ のらにエナメル滴上を被覆し ているセメント粒と考えられる（図 2-1 B，C）。その部 分をさらに高倍率で観察すると,さらに小さな石灰化球 と思われる隆起が認められる（図 2-1 E)。

これは, 同様な部位の透過電顕像所見 (図 9) より確 認された歯根膜線維束の付着部であり,この線維が歯周 病変により表面が破壊され滑択になっていると考えられ る。つまり，エチレンジアミンにて処理を行ったために 脆弱な線維はほとんど除去され, セメント質の石灰化表 面が認められる(図 2-1 E)。

症例 3 (図 3-1) も同様で周囲セメント質は，低倍率で 観察すると，平担な面と認められるが，高倍率では，図
2-1のように半球状隆起が認められ，その表面がささく れだっていて,シャーピー線維の断端と思われる。また石 灰化表面を露出させている部位も存在した（図 3-1 D)。 これらも，エチレンジアミン処理を行っているが，本来 のセメント質の形態を比較的保ち, シャーピーの線維束 を埋大させる石灰化が生じている状態と思える。

症例 4 の拡大像 (図 4-1 C, D, G, H) に抒いて子線維の 断端が表面に認められる。またある部分には, 歯石と思え る石灰化沈着物が認められ，細菌の存在した部分と思わ れる所見も観察できた（図 4-1 E，F）。さらに分岐部セ メント質表面には，随所に小孔が認められ（図 5-1 A), 露出したエナメル小滴表面と思われる凹みには, 細菌の 集落らしい像が観察できた（図 5-1 C, D, E)。

図 6-1 のセメント質表面の隆起部は平滑で線維の埋入 は認められない。 


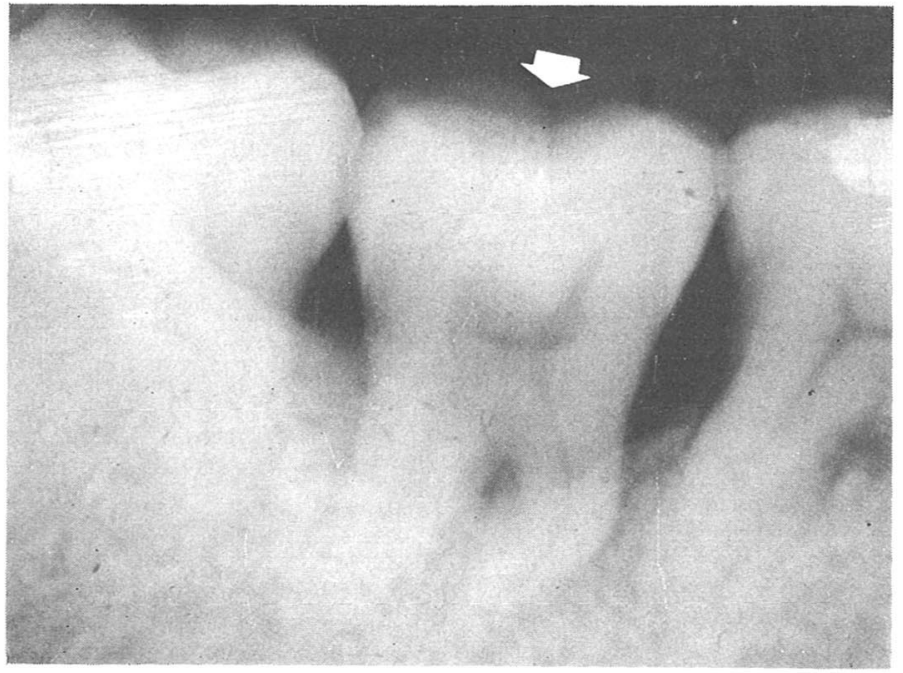

図 2-2 症例 2

우 39 歳 $\overline{7}$

7 年前より歯肉からの出血等の出血があったが，痛みがないため放 置。歯周 ポケット測定值は, 舌側 $4 \mathrm{~mm}$, 類側 $3 \mathrm{~mm}$, 昭和 54 年 2 月 15 日抜歯。X線写真上では, 近心部から分岐部にかけて歯槽骨の 吸収が認められる。

一方, エチレンジアミン原液 $37^{\circ} \mathrm{C}, 48$ 時間作用させ た症例 7 において（図 7-1），中央 D,E, F は，根分岐部 表面の全体像であり，左側は，線維が存在している部 分, 右側は線維の存在はほとんど認められず, セメント 小腔が観察できる部分と，同一症例においても，部位に よって様相に変化が認められる。

図 8-1 の症例のように太い線維束の存在が認められる ものもあった。

\section{IV. 考察}

分岐部を含む研磨切片の所見の報告において，多根歯 では, 分岐部の中程まで伸びているエナメル突起, そし てその先端に点在して, セメント質面に露出しているエ ナメル小滴，もしくはセメント質に覆われているエナメ ル小滴など，異所性エナメル質の大変多いことが認めら れている。それらの表面は平滑で, 線維の付着部は存在 しない。ゅえに，歯周疾患眻患により炎症が波及し，シ ヤーピー線維の破壊が始まると, 異所性エナメル質の表 面において, 容易に歯周ポケットとなり, 病変を増悪さ せる結果となりうる。

なお, セメント質に覆われているエナメル小滴であっ ても, 根面に急性炎症が存在すると, セメント質の表面
の吸収が生じ，表面は多孔質となり，それらのエナメル 小滴の表面が徐々に露出する可能性が充分に存在する。 また根面に沈着する歯石は，セメント質基質に浸透し内 部で成長した結果セメント質を剝離するという報告もあ る21)。一方，セメント質に被覆されているエナメル小滴 のミクロラジオグラム観察所見より，エナメル小滴とセ メント質の間に透過性の高い層が存在しているように認 められた。すなわち，何らかの刺激を受けることにより 被覆セメント質の剝離は, いっそう容易であるかもしれ ない。また臨床面に掠いて, 長く伸びたエナメル突起を 持たない多根歯の治療が成功しない例がある。それは, 前述のように分岐部に歯根膜に接するあるいは，接する 可能性のあるエナメル小滴が存在するためと思える。

エナメル突起の先端やエナメル小滴は, 歯冠部エナメ ル質と発生学的に比較して, エナメル髄の存在は乏し く, 分化の程度も低いと考えられ, 同様な小柱構造を保 つことは難しいと思えるが，ミクロラジオグラムの観察 によると, 歯冠部エナメル質と同程度のX線不透過性を 示し, 偏光顕微鏡観察においても, 歯冠部エナメル質と 同様な複屈折を有することが確認されている。

抜去歯のエチレンジアミン処理の方法は次の通りであ る。 

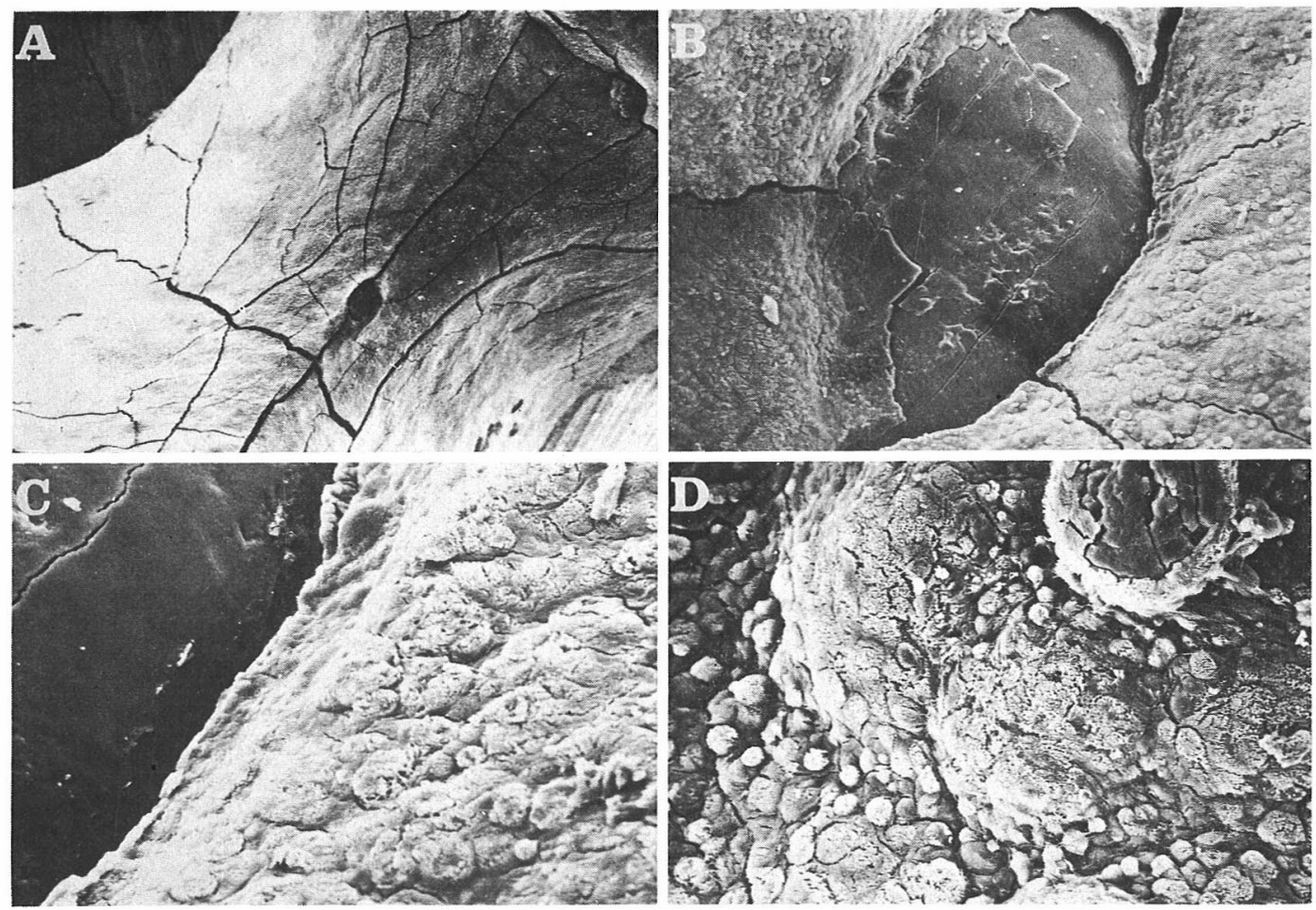

図 3-1 エチレンジアミン原液 $60^{\circ} \mathrm{C}, 12$ 時間処理
A : $\times 30$
$\mathrm{B}: \times 300$ エナメル小滴
C : $\times 1,000$
$\mathrm{D}: \times 3,000$ シャーピー線維を歯根に接着しているセメント質は正常像を示す。

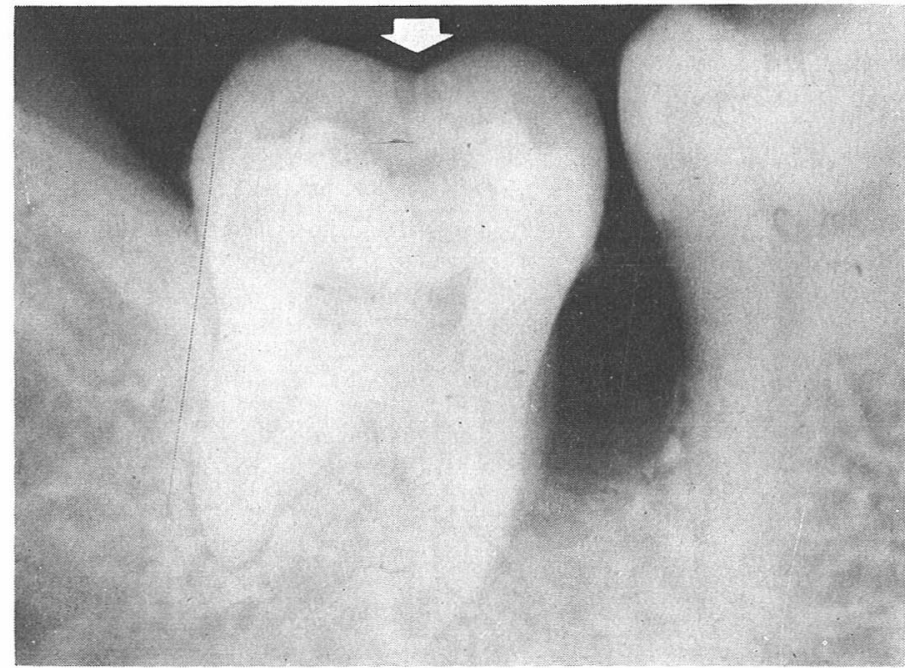

図 3-2 症例 $3 \square$ 今 40 歳 7

歯周ポケット測定值は, 近心舌側 $13 \mathrm{~mm}$, 近心煩側 $13 \mathrm{~mm}$ 。X線写 真上では近心歯槽骨の吸収が著明であるが，分岐部の吸収像は認め られない。 

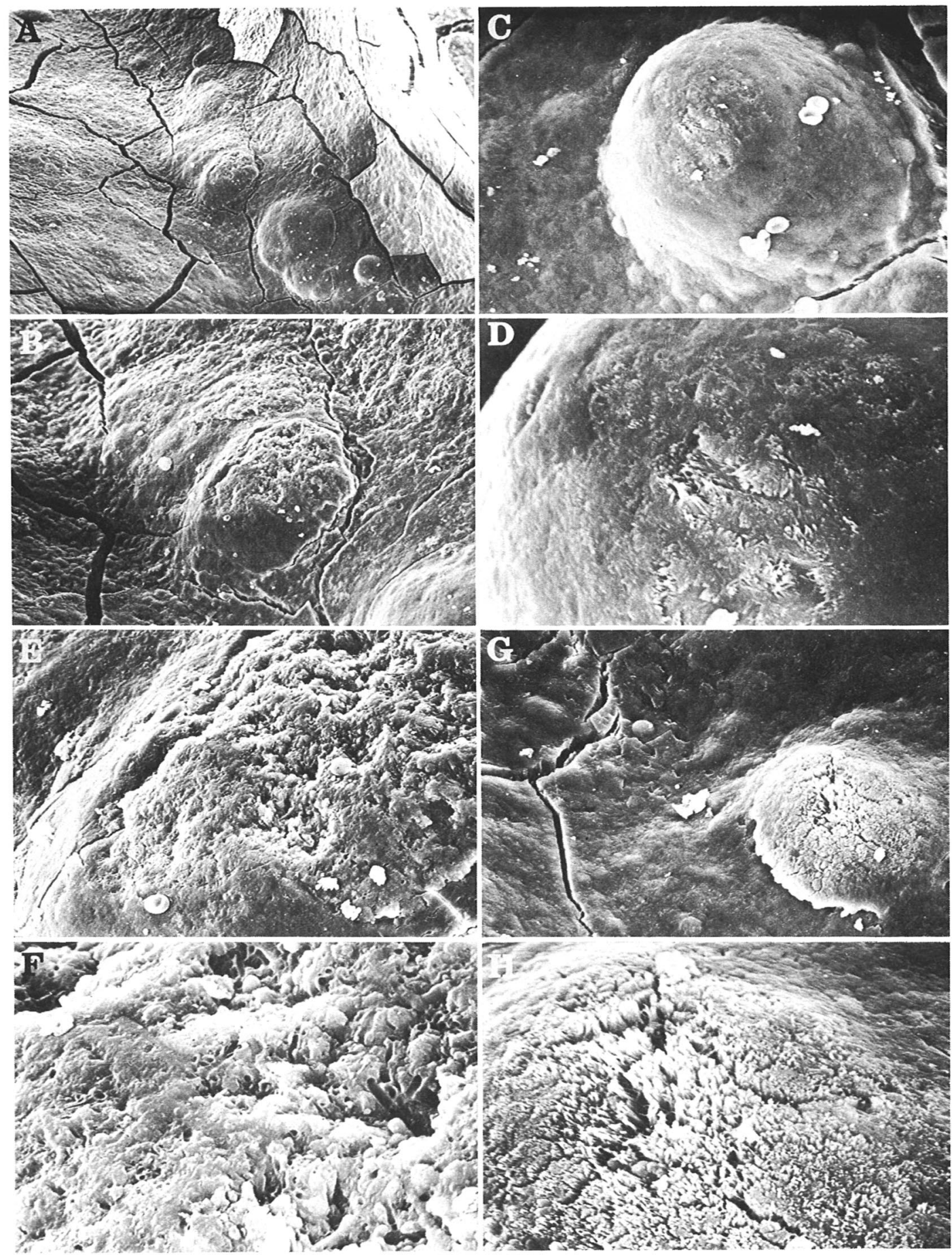
I.

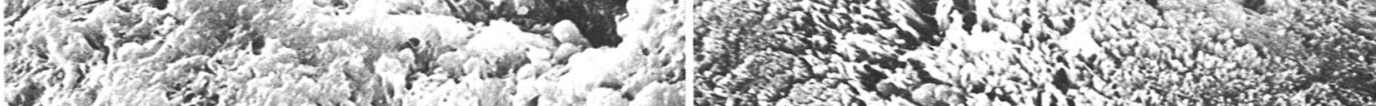

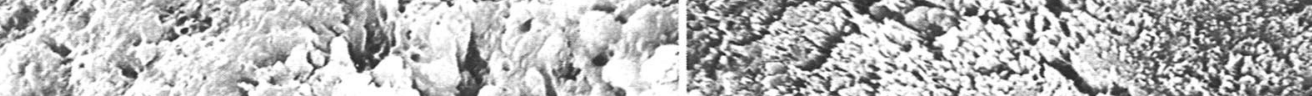

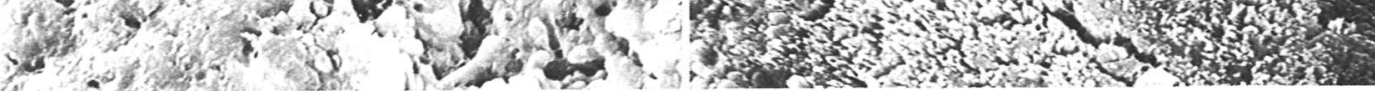

図 4-1 エチレンジアミン原液 $60^{\circ} \mathrm{C}, 24$ 時間処理

A : $\times 100 \quad$ B : $\times 300$ Aの拡大 $\quad \mathrm{C}: \times 1,000$ セメント粒 $\quad \mathrm{D}: \times 3,000$ Cの拡大。表面に 線維の断端が認められる。 $\mathrm{E}: \times 1,000 \quad \mathrm{~F}: \times 3,000 \quad \mathrm{E}$ の挔大。歯石と思われる石灰化沈着物。 $\mathrm{G}: \times 1,000 \quad \mathrm{H}: \times 3,000 \mathrm{G}$ の拡大。セメント粒の表面にやはり線維の断端が認められる。 


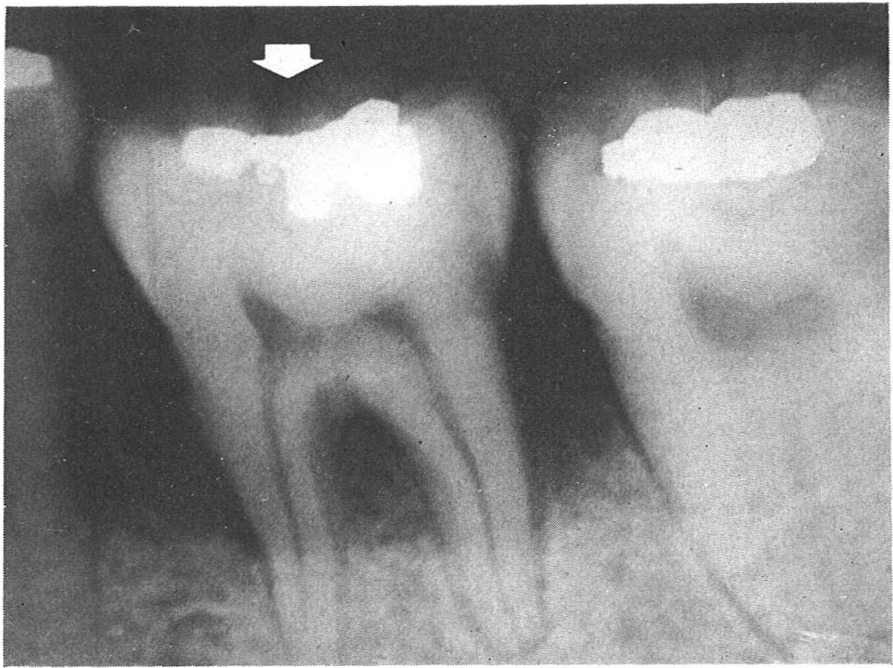

図 4-2 症例 4

+ 41 歳 $\longdiv { 6 }$

15 16 年前項より口腔内全体にわたり歯肉の腫脹が認められた。 歯周ポケット測定值は, 舌側 $4 \mathrm{~mm}$, 煩側 $5 \mathrm{~mm}$ と記録されている が, X線写真上では歯槽骨の吸収像は激しく, 分岐部の病変もかな り進行していると思える。昭和 53 年 7 月 26 日拔歯。

エチレンジアミン原液

$37^{\circ} \mathrm{C} 48$ 時間 症例 6(図 7)

症例 $7($ 図 7-1.2)

$60^{\circ} \mathrm{C} 24$ 時間 症例 $4($ 図 4-1.2)

$60^{\circ} \mathrm{C} 48$ 時間 症例 1 (図 1-1.2)

$60^{\circ} \mathrm{C} \quad 72$ 時間 症例 2(図 2-1.2) (図 6)

症例 $3($ 図 $5-1 \cdot 2)$

生理的に蒾根膜は, 増令と共に線維束の成熟が認めら れるはずだが, 症例 6 (図 7)の所見より, 病変の波及し た部位の埋入している線維束の破壊が起こり，線維束は 脆弱になっており，エチレンジアミンの作用により消失 しやすくなったと考えられる。これは，同条件で処理し た，X線写真においても分岐部病変は認められない症例 7 (図 8-2)の分岐部の線維束が明膫に残存していること 加もいえる(図 8-1)。

歯肉の腫脹が激しく, 分岐部病変が進行している症例 4(図 4-2) に执いても部位によって，七メント質表面が やや平滑な部位 (図 4-1A), 線維の断端が認められる部 位（図 4-1 C, D, G, H), 線維の埋入が認められず石灰 化沈着物が存在する部位（図 4-1 E, F) が観察される。 歯周ポケットの存在により口腔内環境に根面が露出状態 となると, 様々な様相を示すことが暗示される。症例 1 （図 1-2）と症例 3（図 3-2）を比較すると, 症例 3 の処 理時間が長いにもかかわらず，本来のセメント質表面構
造をより保っていると認められる（図 3-1 D)。すなわち 症例 1 のセメント質表面は退化傾向にあると考えられ る。このことは, 臨床所見上において, 症例 3 と比較し て症例 1 の病変は進行して動摇も著しいことからも一致 する。

症例 5 (図 5-2)の根面には, 歯周ポケットの深さを裏 うけるように，細菌の集落と思える像を示す（図 5-1 D, E)。

症例 6 (図 6)のセメント粒の表面は平滑で線維の埋入 は認められない。それらと同様部位をルテニューム・レ ッド染色および EDTA 脱灰を行った透過電顕像では, 同心円状の層板構造を持ち，核に相当する部分は網目状 と認められる。その部分は有機質に富んだ物質ではない かと観察される。又, 外周にはコラーグン線維が認めら れたが，正常なコラーゲン線維束の構造を示すものでは なかった (図 9)。

さらに，研磨切片におけるセメント粒の観察では，ミ クロラジオグラム上で，周囲セメント質よりも透過性が 低い，しかし偏光顕微鏡による観察では, 周囲セメント 質と同様な複屈折性が認められず，光学的等方性であっ た。つまり，非晶質の無機成分が多量に含まれている状 態と思われる。

セメント質の添加において，第 2 セメント質が球状石 灰化を継続することが観察できる。ゆえに，セメント質 


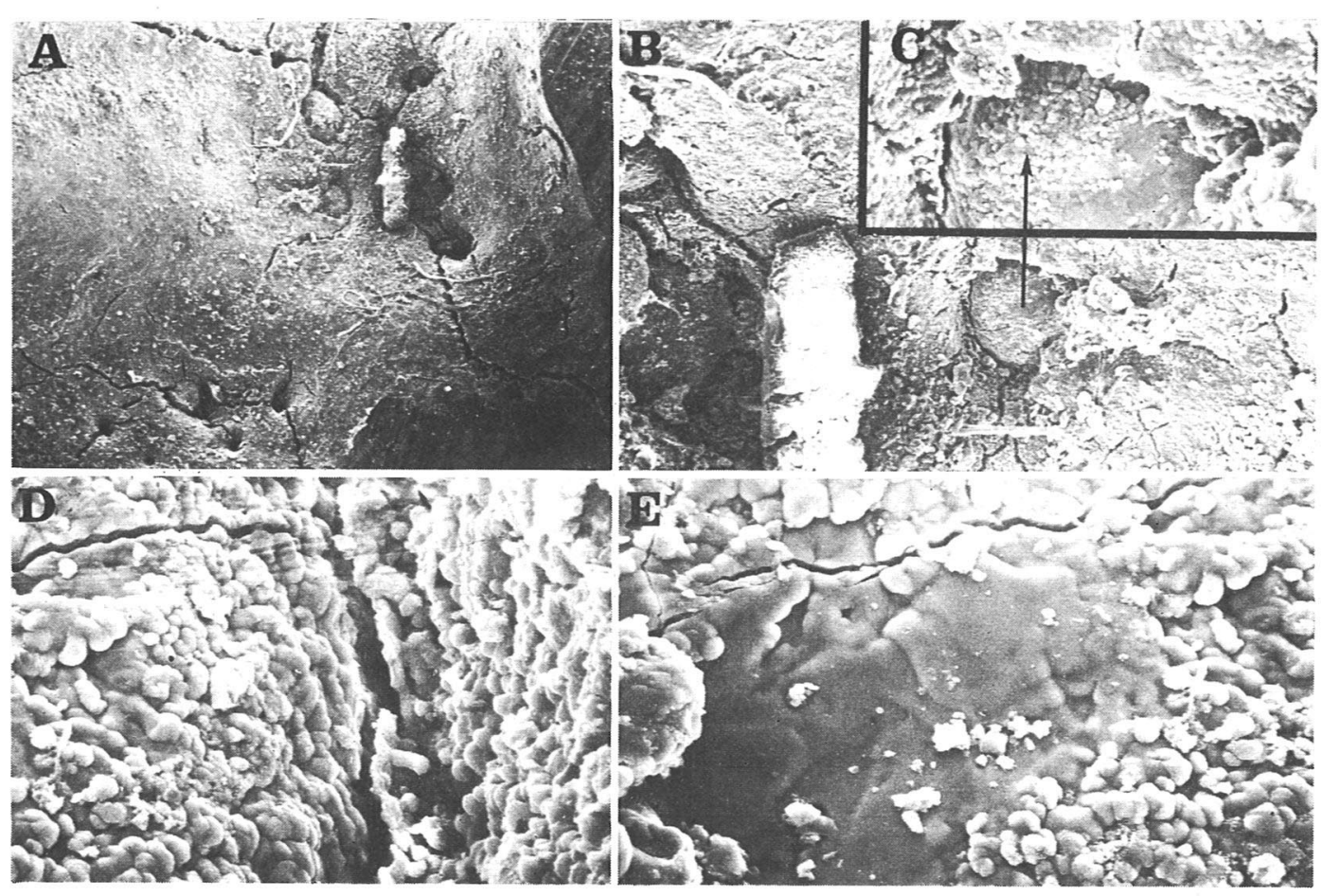

図 5-1 エチレンジアミン原液 $60^{\circ} \mathrm{C}, 72$ 時間処理
A : $\times \quad 30$
B : $\times 100$
C : $\times 300$
D : $\times 1,000$

$\mathrm{E}: \times 1,000$ 歯周ポケット内の歯根表面のセメント質に細菌のコロニーを認める。

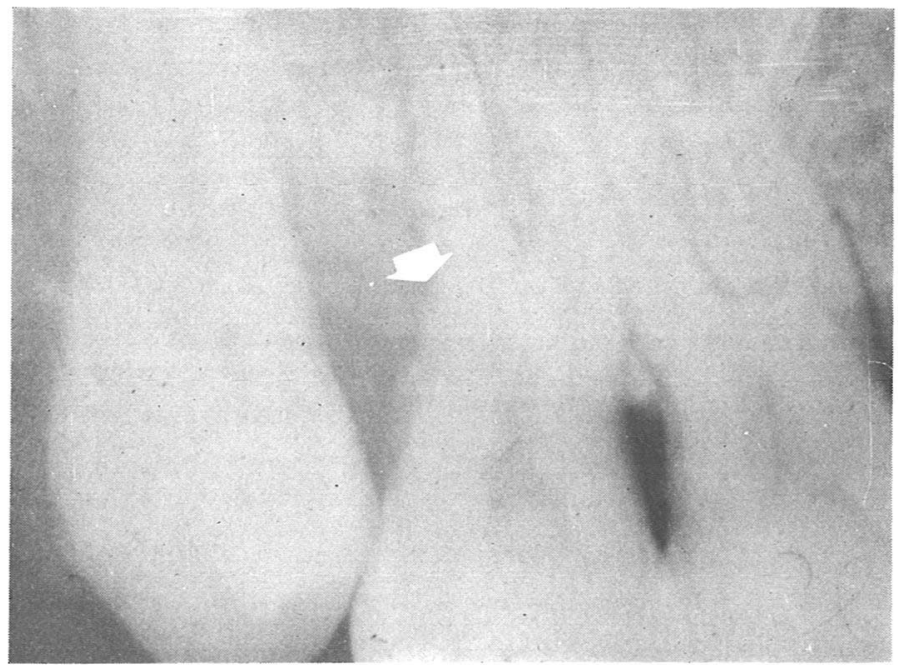

図 5-2 症例 5

우 39 歳 7

症例 2 と同一患者の歯である。歯周ポケット測定值は口蓋側 $6 \mathrm{~mm}$, 煩側 $6 \mathrm{~mm}$ である。X線写真上, 近遠心の歯槽骨の吸収像は著し い。昭和 54 年 2 月 21 日抜歯。 


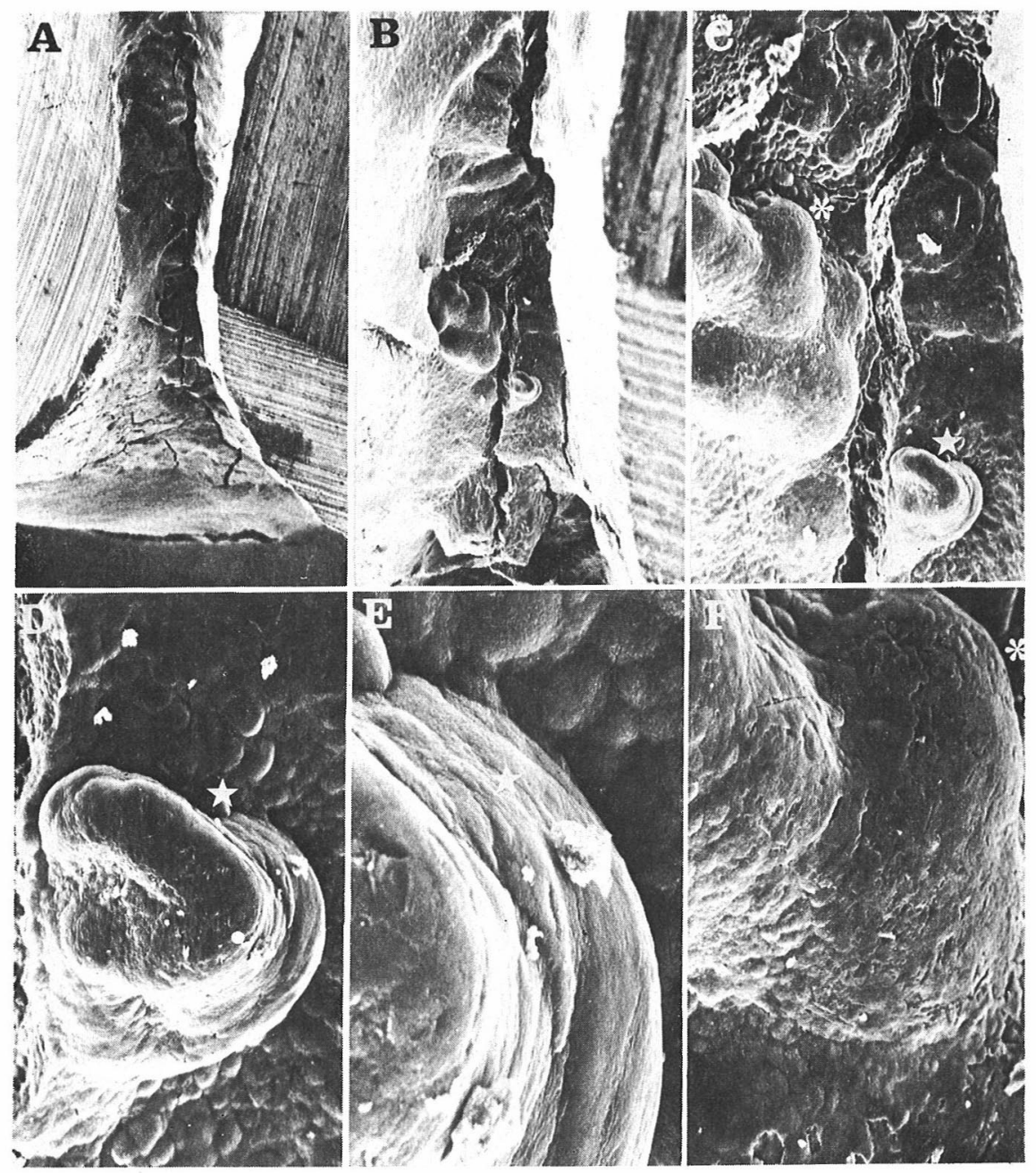

図 6 エチレンジアミン原液 $60^{\circ} \mathrm{C}, 72$ 時閒処理

A : × 30 分岐部セメント質

$\mathrm{B}: \times 100$ Aの拡大

C : × 300 セメント粒

D : $\times 1,000$

$\mathrm{E}: \times 3,000$

$\mathrm{F}: \times 1,000$ 線維の埋人が認められるセメント粒。

症例 2 と同一歯の観察である(図 2-2)。

表面の半球状隆起は, 正常なセメント質添加における結 果とも考えられるが, 周囲セメント質と比較して, 著し い凹凸はエナメル小滴を囲むセメント質に認めることが V. 結 論 できる。

1. エナメル突起が発達している分岐部には, エナメ ル小滴の存在が多数認められる。また根分岐部まで達し ているエナメル乫起の先端および，エナメル小滴は，七 メント質に被覆されている場合と，一部が露出している 


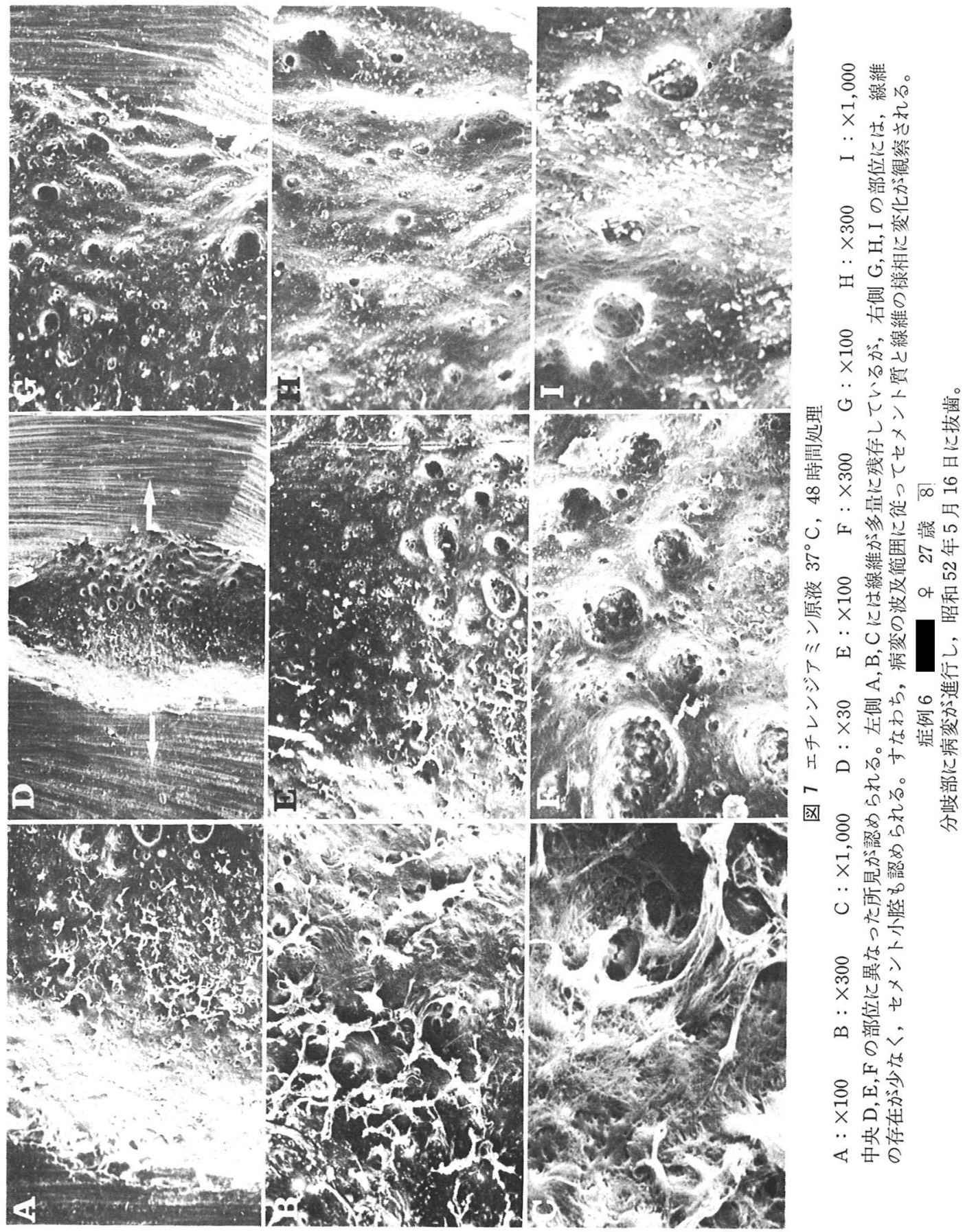



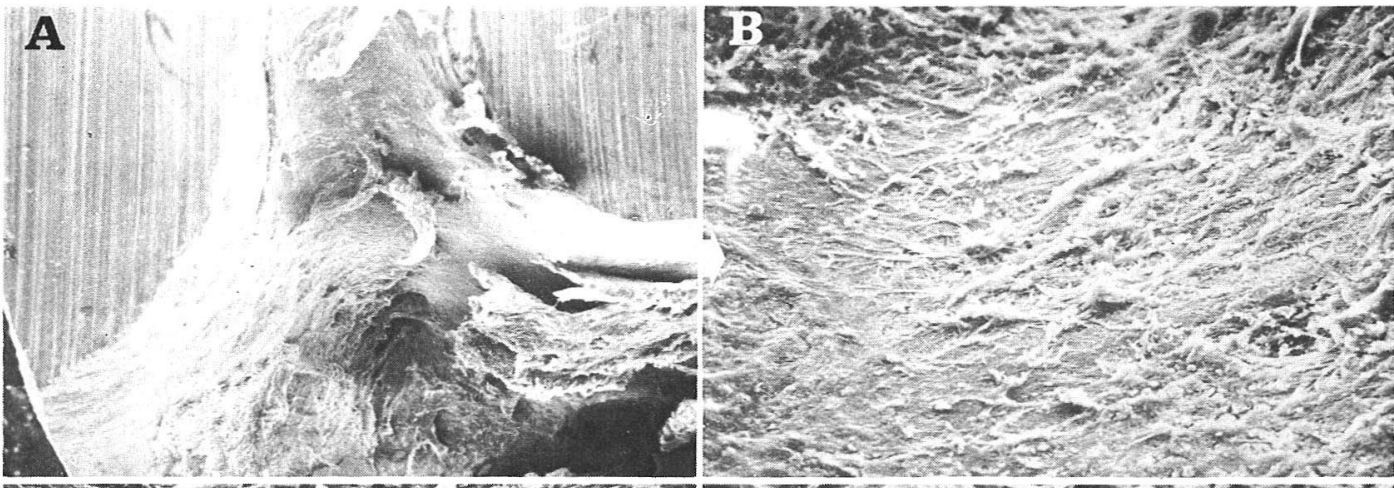

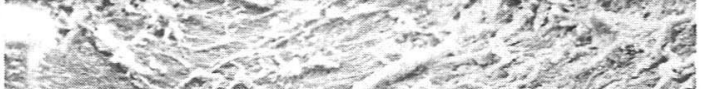

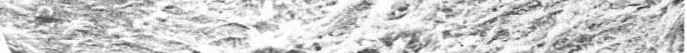

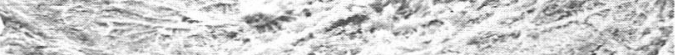

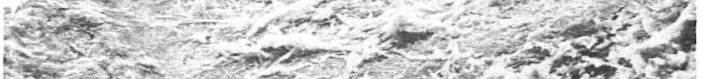

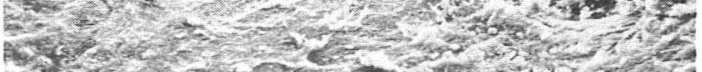

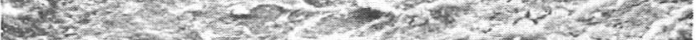

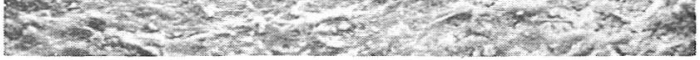

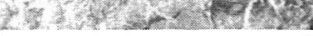

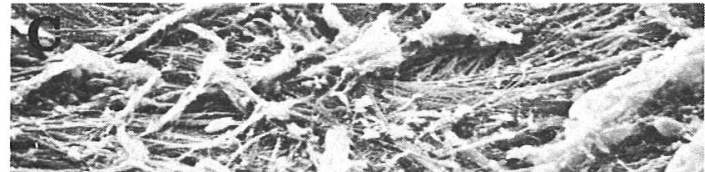

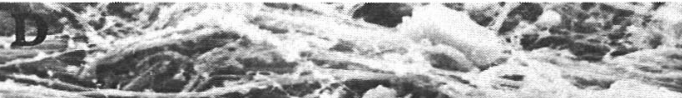

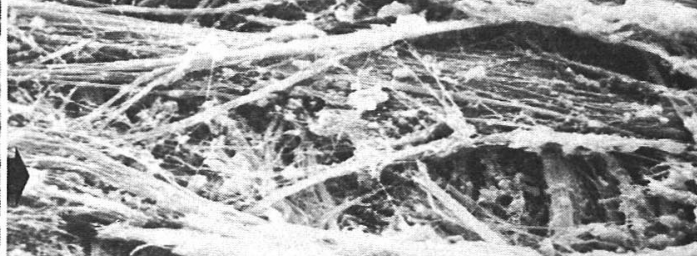

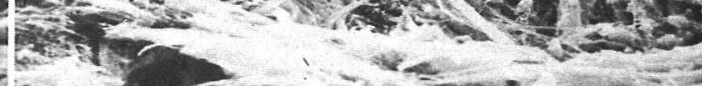

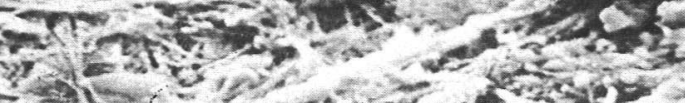

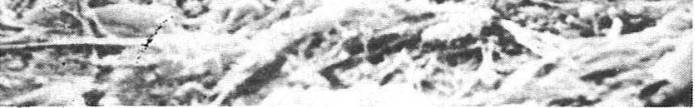

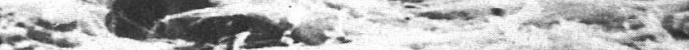

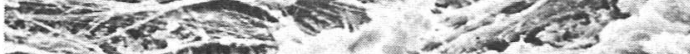
- 5 का

Pas.

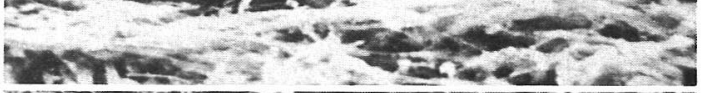

Dis

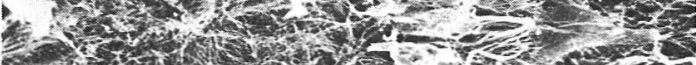

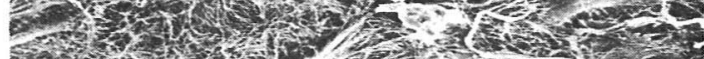
S.
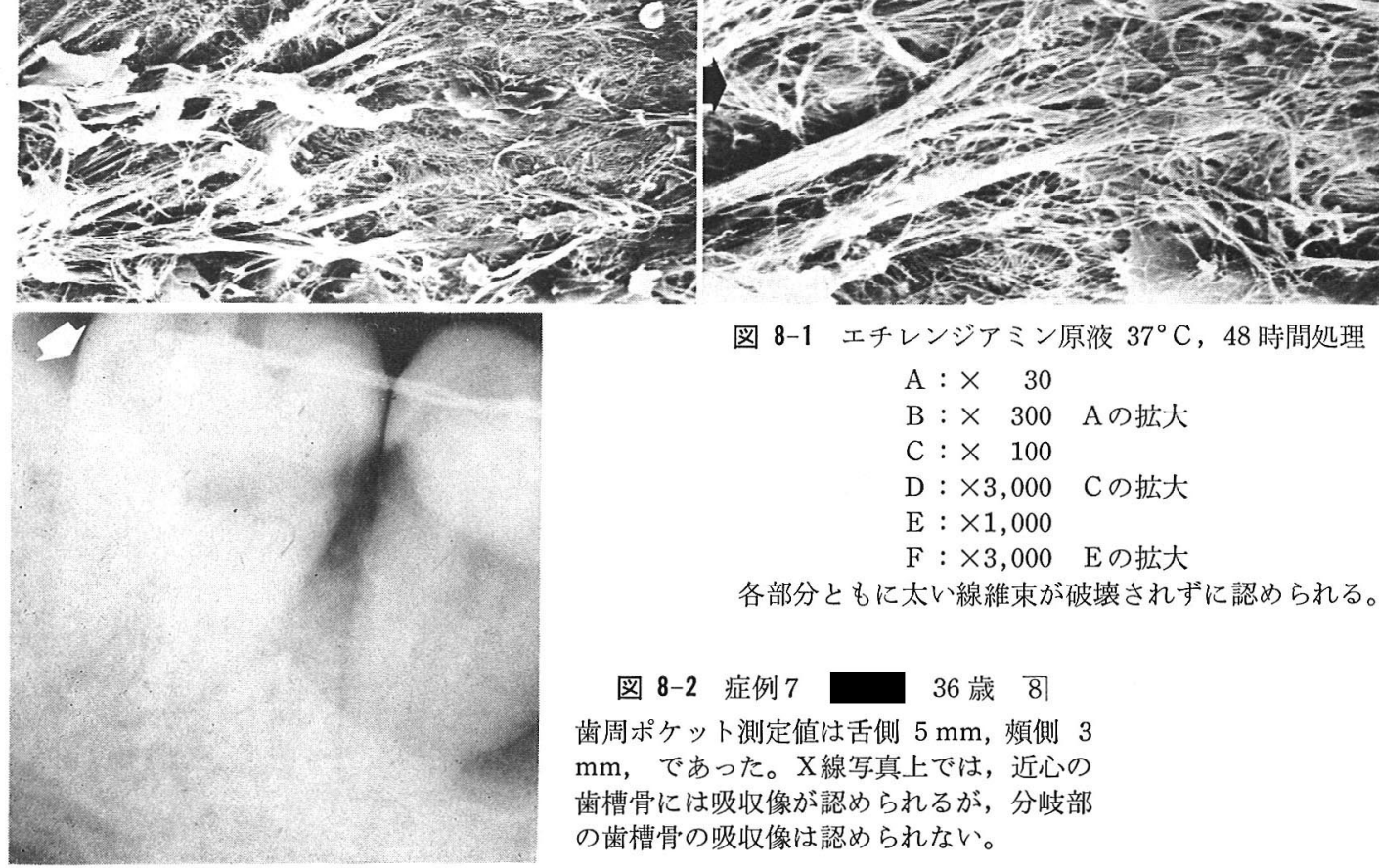

図 8-1 エチレンジアミン原液 $37^{\circ} \mathrm{C} ４ 8$ 時間処理
A : $\times \quad 30$
$\mathrm{B}: \times 300$ Aの拡大
$\mathrm{C}: \times 100$
$\mathrm{D}: \times 3,000 \mathrm{C}$ の拡大
$\mathrm{E}: \times 1,000$
$\mathrm{F}: \times 3,000 \mathrm{E}$ の拡大

各部分ともに太い線維束が破壞されずに認められる。

図 8-2 症例 7 36 歳 8

歯周ポケット測定值は舌側 $5 \mathrm{~mm}$, 頓側 3

$\mathrm{mm}$ ，であった。X線写真上では，近心の

歯槽骨には吸収像が認められるが，分岐部

の歯槽骨の吸収像は認められない。 

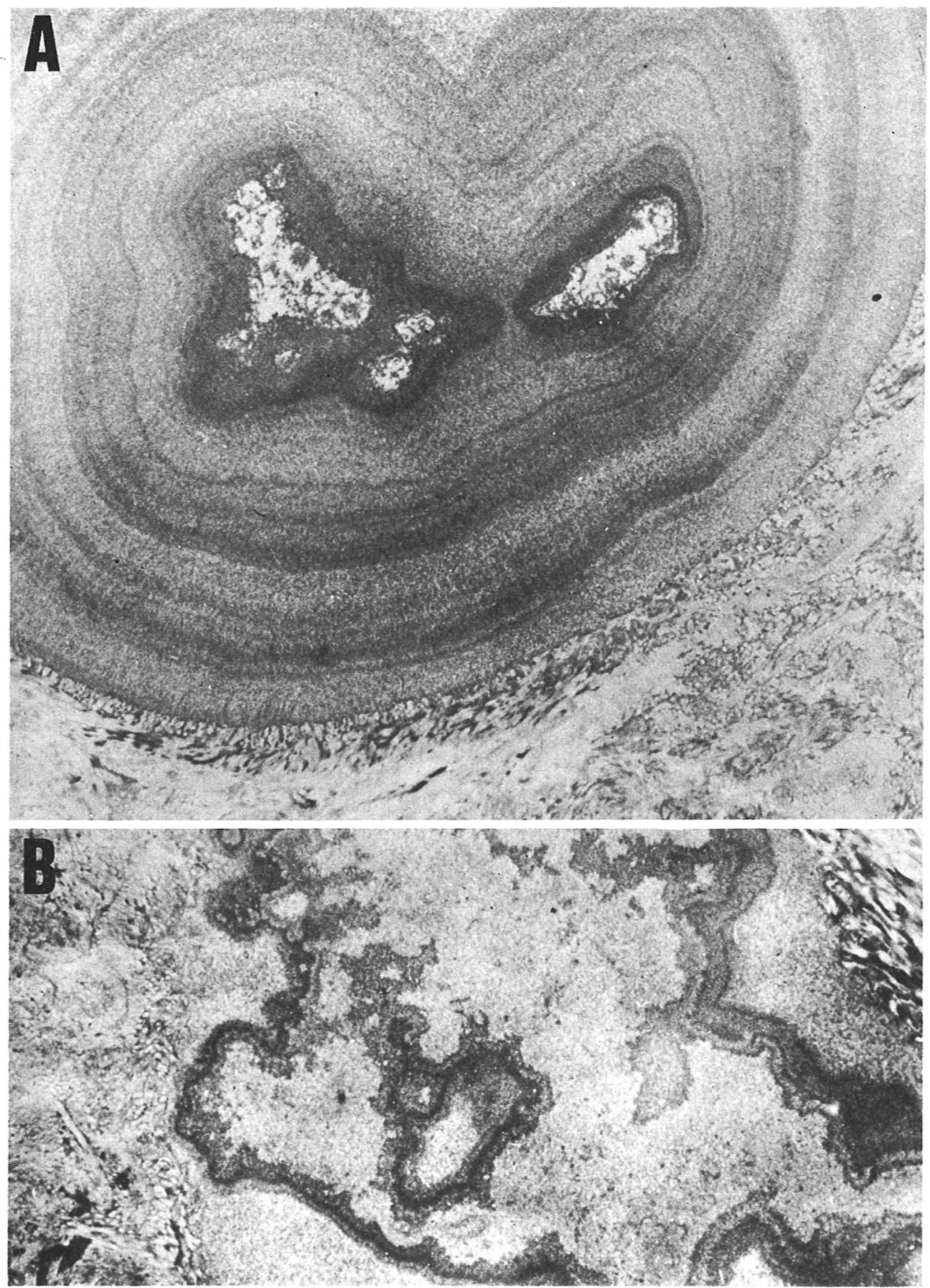

図 $9 \mathrm{~A}: \times 3,000 \quad \mathrm{~B}: \times 3,000$ セメント粒の透過電顕像 


\section{場合がある。}

2. エナメル突起, エナメル小滴の走查電顕による観 察において，歯冠部エナメル質と比較して表面状態は同 様と思えるが, 内部の小柱構造に違いがあることも考え られる。

3. 七メント粒の構造は, セメント質表面に半球状隆 起として分岐部に認めることができた。症例により病変 の程度の違いによるものか, 線維の付着部が認められる ものや認められないものが観察された。セメント粒の透 過電顕所見は, 層板構造を示し, 中心の核に相当する部 分は，有機成分が含まれていると考えられる。

4. 病歴が古く, 歯周病変の進行した歯根面の観察に おいて, シャーピー線維の破壊, 細菌, 石灰化沈着物な どの存在が認められた。

\section{文献}

1) Hamp, S.E., Nyman, S., and Lindhe, J. : Periodontal treatment of multirooted teeth. Results after 5 years., J. Clin. Periodnt., 2 : 126-135, 1975.

2) Gher, M.E., and Vernino, A.R. : Root morphology-clinical sigmificance in pathogenesis and treatment of periodontal disease., J. Am. Dent. Assoc., $101:$ 627-623, 1980.

3) Everett, F.G., Jump, E.B., Holder, T.D., and Williams, G.C. : The intermediate bifurcational ridge :A study of the morphology of the bifurction of the lower first molar., J. Dent. Res., $37:$ 162-169, 1958.

4) Burch, J.G., and Hulen, S. : A study of the presence of accessoey foramina and the topography of molar furcations., Oral Surg., 38 : 451-455, 1974.

5) Lowman, J.V., Burke, R.S., and Pelleu, G.B. : Patentaccessory canals :Incidence in molar furcation region., Oral Surg., 38 : 580-588, 1973.

6) Vertucci, F.J., and Williams, R.G. : Furcation canals in the human mandibular first molar., Oral Surg., 38 : 308-314, 1974.

7) Cavanha, O. : Enamel pearls. Oral Surg.,19: 373-382, 1965.

8) Masters, D.H., and Hoskins, S.W. : Projection of cervical enamel into molar furcations., J.
Periodontol., 35 : 49-53, 1964.

9) Leib, A.M., Berdon, J.K., and Sabes, W.R. : Furcation involvements correlated with enamel projections from the cementoenamel junction., J. Periodontol., 38 : 330-334, 1967.

10) Bissada, N.F., and Adbelmalek, R.G. : Incidence of cervic al enamel junction and its relationship to furcation involvement in Egyptian skulls., J. Periodontol., 44 : 583-585, 1973.

11) Swan, R.H., and Hurt, W.C. : Cervical enamel projections as an etiologic factor in furcation involvement, J. Am. Dent. Assoc., $93: 342-$ 345, 1976.

12) Larato, D.C. : Furcation involvements: Incidence and distribution., J. periodontol., 41 : 499-501, 1970.

13) Ooë, T. : A popos de la formation de la bifuration ou tripartition des racines dans les molaires humaines., Acta. anat., 82 : 512-524. 1972.

14）大江規玄 : 歯の発生学, 医歯薬出版, 東京, 1978 .

15) Ooë, T. : La lame dentaire latérale et la niche de l'émail., Acta. anat., 92 : 259-271, 1975.

16) Ooë, T. : Human-Tooth and Dntal Arch Development., Ishiyaku-Publishers, Tokyo, 1981.

17) Kovacs, I. : Contribution á l'étude de la morphologie ontogenetique des racines humaines., Bull. int. Rech, Sci. Stom., 6 : 95-124, 1963.

18) J $\phi$ rgensen, K.D. : Macroscopic observations on the formation of the subpulpal wall., Odont. Tideskr., $2: 83-103,1950$.

19) Grewe, J.M., Meskin, L.H., and Miller, T. : Cervical enamel projections; Prevalence, location, and extent; with associated periodontal implications., J. Periodontol., $36: 460-465$, 1965.

20）鈴木忠清 : 人の多根歯根間部に現れるエナメル質 の形態と好発面, 口病誌, $25: 273-280,1958$.

21）東 昇平, 小高鉄男, 小林美由紀, 井村哲子, 中 川宏明：歯石がセメント質におよぼす影響につい ての組織学的研究, 歯基礎誌, $20: 669-689$, 1978.

22）松江一郎, 福島祐二, 清水 徹, 荻野智子, 塩入隆 行, 秋重成孝, 石川一郎, 桐野忠昭, Zimmerman, E.R. : 歯周疾患の根分岐部病変の病理組織学的研 
究 (エナメル小滴, セメント粒, 分岐部病変につ (て), 日歯周誌, $24: 143-156,1982$.

23）岩野清史, 清水 徹, 清水欽也, 太田隆温, 白镸
仁, 柴田達美, 松江一郎 : 根分岐部病変とエナメ ルプロジェクション, 日大口腔科学, $1: 83-88$, 1975. 